\title{
CTH: Communication of Organic Adhocracy Empowerment of MSMEs Large Family
}

\author{
Tjatur Ermitajani Judi ${ }^{1} \quad$ Burhan Bungin ${ }^{2} \quad$ V. Rudy Handoko ${ }^{3}$ \\ 1. Universitas Widya Mandala Surabaya \\ 2. Universitas Ciputra Surabaya \\ 3. Universitas 17 Agustus 1945 Surabaya
}

\begin{abstract}
This study aimed to understand the organization and communication process of the Cooperative Trading House $(\mathrm{CTH})$ which encouraged micro, small, and medium enterprises (MSMEs) to be more involved in communication to enhance business opportunities. This research used an interpretive paradigm with the Grounded Method Theory (GMT) approach. The data were collected through interviews and documentation. Researchers conducted interviews with $17 \mathrm{key}$ informants including the head of the main organization, expert staff, owners of MSMEs, and trainers. Then, the data were analyzed by a quasi-qualitative design. The results showed that CTH was an adhocracy with an organic structure configuration; a small organization with a basic structure, but it seemed considerable with nearly 7 million members of MSMEs. Grounded Theory is a nonprofit organization such as CTH which can survive and take a strategic role as the head of a large family sustainably by merging into the members' business; involve expert staff, consultants, entrepreneurs, trainers, mentors, and other professionals in the project team; implement empowerment business communication patterns with a spirit of brotherhood, friendship, cooperation to live and nurture, and strengthen each other for the sake of mutual progress; develop ethics of honesty, mutual trust, mutual interest, and fairness in profit sharing. Research findings are discussed in an organizational and communication context.
\end{abstract}

Keywords: Cooperative Trading House, MSMEs, organizational communication

DOI: $10.7176 /$ PPAR/11-2-03

Publication date:March $31^{\text {st }} 2021$

\section{Introduction}

The long-term vision of the Unitary State of the Republic of Indonesia, East Java Province 2005-2025 is "A Leading, Global Competitive, and Sustainable Agribusiness Center." The governor hoped that East Java would be an industrial province based on Small and Medium Enterprises (UKM) that relied on the development of the processing industry. To achieve the vision, it requires a Cooperative Trading House (CTH) as a professional independent institution to handle MSMEs' products in an integrated manner.

CTH functions to mediate product development, packaging, and marketing of various MSMEs' products, especially processed food and beverage based on agroindustry; mediate between producers and potential buyers, especially non-retail buyers; facilitate the development of business networks with domestic and export markets; provide consultation and technical guidance as needed for producers and/or traders from the MSMEs sector, as well

$\mathrm{CTH}$ : Communication of Organic Adhocracy Empowerment of MSMEs Large Family

as convey information on market dynamics and trends, product quality, and packaging to get both non-retail and retail market and; facilitate the needs of MSMEs for access to production, distribution, and marketing technology.

Researchers reflect on $\mathrm{CTH}$ as a typical organization that has challenges in the internal body and organizational communication. First, CTH lives in a business environment. This fact refers to CTH to build communication for the socialization of innovation and learning to face market competition. Second, CTH was deliberately established to answer deadlocks that the previous organizations had not been able to penetrate in carrying out the task of advancing MSMEs. Third, CTH is not a legal entity, but it accommodates most MSMEs with legal status. This fact refers to $\mathrm{CTH}$ as a legitimate organization. This also reflects that CTH must maintain communication that has been constructed in such a way with MSMEs for the advancement of MSMEs itself. Fourth, CTH is a non-profit organization and it does not have budget sources and office buildings independently, but it accommodates profit business organizations. This fact refers to $\mathrm{CTH}$ which can raise itself as an organization integrated into the MSMEs business operations. This also reflects that $\mathrm{CTH}$ must maintain communication with MSMEs for mutual progress. Fifth, CTH has an organizational structure consisting of only a director and three expert staff, but it informally treats MSMEs owners as CTH administrators. This fact shows that $\mathrm{CTH}$ bears a high communication burden with millions of MSMEs' members. Sixth, CTH is not an association, but it can unite and bring together the business interests of members. This fact refers to CTH's ability to shift the mindset of the leaders of the MSMEs from just producing to the mindset of producing and selling and finally to the mindset of looking for products and supplying. This means that CTH must continue to communicate progressively with MSMEs to build richer and broader business insights. 
The study of CTH in the perspective of the organization and organizational communication is under Nonaka and Takeuchi's (1995) statement who mentioned that society had information and knowledge. A communication network allows the flow of messages between communicators across time and space. Business people use creative and intellectual assets to generate value through communication networks. Furthermore, practitioners perceived communication as an important and challenging area that affected an organization's ability to engage employees (Welch \& Jackson, 2007). In the information age, organizational assets include knowledge and relationships of people. The business of the organization obtains input information and uses creative and intellectual assets of employees to be processed to produce value. Internal communication is the core process by which a business can create value (Quirke, 2000). Good communication is vital to a communication network. Organizations had to adopt a strategy so that internal communication flowed quickly and became a major resource for knowledge (Jablin \& Putnam, 2001; Monge \& Contractor, 2003).

The literature showed that organizational communication encouraged members to acquire organizational values; made members feel supported by the organization; stimulated the organization to accept member initiatives; organizations became more competitive; enabled introduction, dissemination, acceptance, and internalization of new (change) values and management guidelines that accompanied organizational development (Welch \& Jackson, 2007); boosted members' participation that encouraged initiative (creativity), and; became a unifying factor, motivation and personal development (Conduit \& Mavondo, 2001; Grunig et al., 2002; Jablin \& Putnam, 2001).

Understanding CTH communication is useful because it encourages MSMEs to be fully involved in the communication process which will further enhance business opportunities. However, the literature on research results in this field is still very rare. This study used an organic organizational structure theory approach, Y theory, Japanese organizational theory, Adhocratic organizational structure configuration theory, information processing theory, and the theory of the Communicative Constitution of Organizations (CCO).

\section{Theoretical and Literature Background}

Organizational communication in CTH occurs in a multi-way, multi-functional, multi-role, and reciprocal cycle. CTH director communicates with staff as a function of coordination and informal reports. Director and staff can communicate with MSMEs' members in their functions and roles as brokers. For example, director or staff can carry out functions and roles in assisting MSMEs' owners to obtain Halal Certificates related to the processed products they produce; as a broker for MSMEs with domestic market stakeholders; as a guide, mentor, or companion for MSMEs; prepare MSMEs' products as suppliers for the domestic retail market such as Indomaret, Alfamart, minimarkets, and other modern markets; as a liaison between MSMEs and brokers, suppliers, users and

\section{CTH : Communication of Organic Adhocracy Empowerment of MSMEs Large Family}

buyers in the domestic market environment with or without going through the Indonesian Retail Entrepreneurs Association (Aprindo), East Java. MSMEs that are already successful and independent, without going through CTH directors or staff, can have direct contact with brokers, suppliers, users, and buyers in the domestic market.

Communication that occurs among MSMEs is also multi-directional and multi-role. One MSMEs at a time can take on the role of a supplier for other MSMEs as a user, at other times one MSMEs can also function as a broker for other MSMEs as a buyer. MSMEs in the context of organizational communication can play a role, either as a broker, supplier, user, or as a buyer, either partially or simultaneously. Partial communication can occur between MSMEs suppliers and MSMEs users, MSMEs suppliers and MSMEs buyers, and MSMEs suppliers and MSMEs brokers. Simultaneous communication can occur between MSME brokers with MSME suppliers and MSME users, MSME brokers with MSME suppliers, and MSME buyers.

Communication processes in CTH are following the internal communication of the organization from Welch and Jackson (2007) that: (1) internal communication in CTH occurs in line managers, namely communication between CTH administrators and MSMEs' owners who are oriented towards giving directions about competitiveness; (2) in CTH there is internal communication among teammates, namely among MSMEs owners who coordinating like a team; (3) in CTH there is an internal communication of project partners, namely between the management and the MSMEs' owners which building communication like two successful teams that support each other, and; (4) in CTH there is internal company communication, namely the chairman of CTH who conveying goals, objectives, new developments, activities, achievements and other matters to the CTH and MSMEs' administrators.

CTH also builds organizational communication with cross-border institutions to seek export market opportunities. These institutions are expected to connect CTH with users, buyers, and brokers so that Indonesian MSMEs' products can penetrate the export market.

The organizational communication processes carried out by CTH appear to be inseparable from the organizational structure, CTH environment, and the interests of MSMEs. This is following the definition of an organization with the organizational structure features proposed by Wrench (2012), at least in three basic 
processes, namely: the external environment, input, and throughput.

CTH's external environment includes all vendors (suppliers and brokers); competitors, customers (users and buyers), and other stakeholders in the domestic and export market environment. The external environment has an impact on $\mathrm{CTH}$ which has open, free boundaries in the flow of information and very adaptive to environmental changes.

Inputs are the resources that $\mathrm{CTH}$ brings from the external environment to achieve its goals. They are physical materials, people, and information. Physical materials or physical materials owned by CTH include offices, product showrooms, a supply of MSME products itself. People are the resources that animate CTH, including the leaders and staff of the East Java Cooperative and MSME Service, Apkrindo directors and CTH expert staff, MSME actors who are members of CTH and suppliers, brokers, users, and buyers. Information refers to any data that an organization needs to have to create knowledge (Atwood, 2009). For example, CTH researches to determine product trends that the market is interested in. Research data can be used for product development.

Throughput is what an organization does with inputs within the boundaries of the organization itself. CTH has a throughput in the form of a basic organizational structure, consisting of a director and three expert staff. $\mathrm{CTH}$ is an adhocratic type that has a very high configuration of organic, decentralized organizational design and delegation of decision-making authority. This is because CTH operates in an external environment of the domestic and export markets which are very dynamic and volatile.

This is similar to the design of division of labor decisions, departmentalization, design of outreach decisions, and design of delegation of authority decisions (Gibson et al., 1994). First, the director and staff of CTH decided to sort all tasks into small tasks in turn that can be carried out by MSMEs owners. The director and staff of CTH sort the overall task activity into a set of related activities. Second, the director and staff of CTH decide the basics of grouping the work of MSMEs. This decision is the same as in other classification decisions and this can result in groups containing relatively homogeneous or heterogeneous jobs of MSMEs. This is called a departmental design decision. Third, the director and staff of CTH decide exactly the size of the MSMEs group that reports. They do not only report to the director together with the CTH expert staff as "superiors," but also "reporting" to fellow MSMEs members. This decision involves determining a broad range of controls. This is known as the surveillance outreach design decision. Fourth, the director and CTH staff distribute authority among MSMEs owners. Authority

CTH : Communication of Organic Adhocracy Empowerment of MSMEs Large Family

is the right to make decisions without the approval of the director or CTH expert staff. This is called the design of delegation of authority decisions.

Communication processes in CTH are following the definition of communication as a process and communication as a channel proposed by Wrench et al. (2008). Communication is a process of a series of interactions that change over time and produce changes in the people involved in the interaction. The success or failure of informative or persuasive efforts can change the way people interact with one another in future interactions. For example, MSMEs' owners who are involved in communicative interactions can partially become a broker, supplier, user, and broker, as well as simultaneously act as a broker, supplier, and at the same time as a user. Communication as a channel shows the communicative interaction processes in CTH are mediated by information technology. Communication as a channel with the mediation of short message applications, electronic mail (email) and WhatsApp, telegram, and others allows messages to be conveyed in a flash between communicants.

Communication processes in $\mathrm{CTH}$ are also following the definition of communication as a two-way process between actors. "Interaction" does not only mean "direct reciprocal dialogue," but also "acting on one another and having an influence on one another" (Neumann, 2008). Interaction does not only refer to the feedback process, as well as a direct interaction between people, but it can also refer to a more abstract concept of interaction related to how people relate to other meanings in developing their meanings (van Ruler, 2018). The focus of interaction, whether mediated or not, is an interpersonal conversation (dialogue). Dialogue means focusing attention on the act of turning in another direction and listening to each other regarding differences to improve the quality of communication (Broome, 2009). The theoretical explanation can be perceived from the meaning of communication actors in CTH. Each communicant can interpret the messages in the communication process. This was mainly because communication developed into a dialogue between individuals between CTH directors, CTH expert staff, and MSME actors. When the communicant presents himself with the interests and goals of being a broker, as a supplier, as a user, and as a buyer, and when the director of CTH and CTH staff position themselves as guides, each communicant will easily understand because they are in a dialogue that strongly supports interpretation.

The communication processes in CTH are also following the theory of the Communicative Constitution of Organizations (CCO). Reality is an explanation in which humans construct themselves through interactive conversations (van Ruler, 2018). The organization emerged "through the laminated flavor-making activity of the 
members, relentlessly renegotiated." People orient themselves toward one another, leading to moments of consensus, but the consensus is constantly being renegotiated. Mutual orientation is a process that occurs constantly in interactions (Taylor \& Van Every, 2000). In communication, what matters is not how individuals understand communication, but how subsequent communication interprets previous communications connected to it; only communicative events can determine the particular way in which the communicative events preceding them are understood (Schoeneborn \& Blaschke, 2014). Interaction is not a matter of how meanings meet, but how meaning is continuously created and developed in a continuous process of conversation (van Ruler, 2018).

Communication processes in CTH are also following the communication lens as a process of Omnidirectional diachronic meaning development. Interaction should be perceived as a virtual process that occurs at the level of interpretation made by the sender and receiver, which influences the meaning people to give to the message and the effect of the message. Judging from this lens, actors are not always related or close to each other (van Ruler, 2018).

The image of communication as a two-way circular (cyclical) process shows what and how a person communicates has an effect that can change future communication. Reciprocal-cycle communication implies that communication returns, in a full circle, to the same point from which communication started (Dance, 1967).

This theoretical explanation can be illustrated that the simultaneous communication between CTH directors, CTH and MSMEs staff and between MSMEs with a broker-supplier-user-buyer cycle is repeated communication and returns to the starting point of communication, namely from the broker to the buyer, from the supplier to the broker, from the user to the supplier, from the buyer to the user, and starts again from the broker.

This illustration is consistent with the statement by Ritzer (2000) that "the general mechanism for selfdevelopment is reflexivity or the ability to place oneself unconsciously in the place of others and act when others act. One can examine oneself just as anyone else will". This explains that in the communication process, the broker will also position itself in the position of the supplier when dialogue with the supplier, and vice versa; In addition to positioning itself as a supplier, a supplier will also position himself as a user when having a dialogue with the user, and vice versa; Users will position themselves as buyers when negotiating with buyers, and so on. These processes

CTH : Communication of Organic Adhocracy Empowerment of MSMEs Large Family

occur to facilitate communication because each of them develops an understanding of one's position in the position of others, so that communication can be maintained and the interests of each can be communicated properly, and each other's goals can be achieved, because of each other. support the achievement of common goals and each makes mutually beneficial decisions.

Communication processes in CTH seem to be communication between individuals only because it is perceived as a communication between the CTH director, CTH, and MSMEs staff and among MSMEs that have a broker-supplier-user-buyer cycle. This is because CTH is a typical decentralized organic organization with a high level of delegation of authority or a low level of centralization and formalization. This is because high centralization and formalization will limit interaction and communication (DeLeon, 1993).

Each section seems to be able to make its own decisions without going through an organizational coordination mechanism with CTH. Indeed, CTH is deliberately designed like that to achieve the goal of advancing MSME members or fostering members to become independent and successful. Communication that occurs in CTH is organizational communication. The progress achieved by MSMEs is the goal of CTH. MSMEs that are already successful and independent can completely separate from CTH to build communication with the domestic market environment and the export market. However, successful and independent MSMEs still want to be with CTH. This shows that CTH has the meaning of being the right organization to accommodate and fight for the interests of MSMEs. Successful and independent MSMEs will shift as assisted MSMEs to become pilot MSMEs and can take on the role of mentoring MSMEs for other MSMEs. The director and staff of CTH and the practitioners of MSMEs have built a collective system for the common goal, "CTH success is MSME success" and "MSME success is CTH success." This is following Mumby's (2013) statement that organizational communication is the process of creating and negotiating a coordinated system of collective meaning through symbolic practices oriented towards achieving organizational goals.

Multi-directional, multi-functional, multi-role and reciprocal communication processes are also following the notion of organizational communication as a phenomenon (Deetz, 2001). Communication between CTH directors, CTH and MSME staff, and between MSMEs that have a broker-supplier-user-buyer cycle can be seen as a specific phenomenon or a series of phenomena in the organization. When partially or simultaneously as a broker, supplier, user or buyer, director and staff of CTH as well as MSME actors, it can be said that they are communicating the organization.

\section{Research Method}

This research used an interpretive paradigm with the Grounded Method Theory (GMT) approach. The data were collected through interviews and documentation. Researchers conducted interviews with 17 key informants, 
namely three leaders from the Office of Cooperatives and MSME of East Java Province as the parent organization, a director and $2 \mathrm{CTH}$ expert staff, as well as $10 \mathrm{MSME}$ actors and a trainer. Then, the data were analyzed by using a quasi-qualitative design.

\section{Results and Discussions}

\section{CTH: Adhocracy with an organic structural configuration}

The structural configuration of an adhocracy is a low level of formalization, organic, selective distribution of decentralized power, work coordination with work quality adjustments requires expertise, and operates in a complex and dynamic environment (Minner, 1988). Covin et al. (1994) characterized organic structures through the attributes of decentralized decision making, informality, and flexibility. This characteristic corresponds to CTH. The CTH Director stated:

"We, CTH administrators and members of MSMEs ... are involved in open communication that flows without obstacles .... coordination can happen automatically... I can make decisions immediately... CTH staff can also make decisions quickly without coordinating with me... because through the application I know... I monitor every communication process... and I already know the direction... know the conclusion I know the decision even though has not been decided yet...."

Berry (1998) characterizes the organic organization with unspecialized job variables and unclear job tasks; loose surveillance coverage, blurred linkages between authorities; Broad communication networks, varied departmentalization, small differences between lines and staff, decentralized decision-making and high levels of delegation, integration using project committees and teams, being in an unpredictable and turbulent environment, unspecialized work and unclear work assignments. This variable corresponds to CTH which does not have the main

CTH : Communication of Organic Adhocracy Empowerment of MSMEs Large Family

duties and functions which are described in detail in each division and position. CTH is a typical organization with a loose scope of oversight because the formal structure of $\mathrm{CTH}$ consists of only one director and three expert staff. It informally treats millions of MSMEs members as supporters of CTH. CTH has an obscure association with the parent organization that does not regulate in detail the authority of $\mathrm{CTH}$. The relationship between the parent organization and CTH in decision making is very decentralized. CTH has a high capacity for delegation of authority because CTH stands for the Cooperatives and MSMEs Office. CTH is an organization that has an extensive communication network with millions of MSMEs. CTH has a basic structure without departments, but the expert staff can momentarily create various parts of a project. For example, they create a promotion, exhibition, expo, bazaar, mentoring, training, development, management of the halal certification process and distribution permits, etc. in the context of progress and development of member MSMEs. CTH with a simple structure has a very decentralized decision-making mechanism and very delegates authority through the development of organizational culture in a very open flow of communication. CTH integrates management and MSME members through committees and project teams consisting of expert staff, entrepreneurs, consultants, assistants, trainers, and other professionals. CTH aims to advance MSMEs to be competitive in both the domestic and export markets. Meanwhile, the market itself is an environment that is very dynamic, fast-changing, full of turbulence due to competition, and difficult to predict.

\section{Communication of CTH Large Family Empowerment}

CTH has been interpreted as a house or large family with the character of lateral empowerment communication because it is dominated by communication between MSME actors who are CTH members and the number is $6,825,931$. The thematic analysis shows that the large family is the main theme carrying the themes of empowerment communication under with the spirit of brotherhood, friendship, cooperation to live and support and strengthen each other for mutual progress; share, consult, motivate and inspire each other; develop ethics of honesty, mutual trust, mutual interest, and fairness in profit sharing. The themes emerge from the results of interviews with key informants.

The theme of a large family emerges in the sample interview with Pak Bambang Irawan:

"CTH is like a household that has MSMEs as the members. CTH is parents, established and independent MSMEs are the eldest children.... The developing MSMEs are the middle children.... Underdeveloped MSMEs are the youngest children... expert staff, consultants, trainers, mentors, professionals share the friends of MSMEs actors..."

The terms "parent" and "child" refer to the application of Japanese organizational theory, namely that organizations are very paternalistic, taking responsibility for the lives of their employees (MSMEs). Employees (MSMEs) are committed and loyal to the organization (CTH). Work is for life, company (CTH) becomes part of personal identity. Jobs tend to be large and less specialized; employees (MSMEs) participate in decision making which in turn reinforces tasks that focus on product quality (Berry, 1998).

The terms "eldest", "middle", and "youngest" describe the theme of brotherhood. MSMEs who are already 
independent will take on the role of inspirers and consultants for developing MSMEs. The developing MSMEs will take a more role as a motivator for the underdeveloped MSMEs. This theme appears in the sample of lateral communication between MSMEs as suppliers and others as buyers. Communication occurs in business communication of sharing profit, trusting and protecting each other's interests, empowering, inspiring, and motivating. Samples of interview result from Mr. Syafi'i, an MSME actor, a coffee shop "Ebez" in Sidoarjo Regency and a coffee shop "Memez" in Mojokerto Regency in business communication with Pak Hartono, an MSME actor of "Mak'e" coffee powder products from Tuban Regency, stated:

“.... After routinely trying for a week, I give my appreciation.... 'Wow, this fits.'... I think coffee is good for drowsiness, especially if you are very sleepy when you drink... it feels good... drowsiness goes away... your eyes immediately 'light up'... the taste of coffee is addictive... when you take a break or chat, you want to drink, I also gave Pak Hartono input for "Mak'e" coffee because coffee is "made by Mother," so traditionally the color has to be dark black because it seems that it is processed manually, even though the ground coffee must be evenly smooth..."

The sample from the interview with Pak Hartono stated:

“... Mr. Syafi'i on his initiative gave me the feedback I needed to improve my ground coffee... so that it could be more accepted by customers.... I also became more positive ... I gave the 'secret recipe' how the

CTH : Communication of Organic Adhocracy Empowerment of MSMEs Large Famliy

best "Mak'e" coffee is served... coffee is still good to drink when it's hot or when it's still warm... I guarantee that coffee connoisseur will finish the coffee before it gets cold... and ask for it. add another glass...."

The success of the coffee shop "Ebez" prompted Pak Syafi'i to open a coffee shop "Memez" in Mojokerto. The total demand for ground coffee in "Ebez" and "Memez" coffee shops averaged 8 quintals per month. Business communication between Pak Hartono and Pak Syafi'i is based on mutual trust. When the new "Memez" coffee shop opened, Pak Hartono made concessional payments on a consignment basis and intended to help the "Memez" coffee shop develop rapidly. After the coffee shop "Memez" was sold out, Pak Syafi'i was no longer willing to pay by convention but paid in cash.

Pak Hartono - Pak Syafi'i communication developed into mutually 'legalizing' communication. Pak Hartono sent coffee in an unlabeled form. The coffees that became famous were "Ebez" coffee in Sidoarjo and "Memez" coffee in Mojokerto. Pak Hartono did not object, because what later became famous was the "Ebez" coffee brand and the "Memez" coffee brand. "Ebez" and "Memez" are just a stall and what is sold and enjoyed is coffee made by "Mak'e." Business communication similar to that also occurred between Bu Rahayu in Malang and Mbak Mi in Jombang. Bu Rahayu produces pecel spices, while Mbak Mi is the owner of "Warung Nasi Pecel MBak Mi." Bu Hahayu supplies unlabelled pecel seasonings. "Warung Nasi Pecel mBak Mi" is selling well and has become so famous with the image of the pecel rice taste that is different from other typical pecel rice stalls, but behind it all, what customers enjoy at the "mBak Mi" pecel rice shop is Bu Rahayu's artificial pecel spices from Malang City.

Lateral communication also occurs between suppliers, brokers and buyers. MSME brokers do not produce the same goods or services as MSME suppliers. An MSME actor in business processes inside CTH and also outside CTH meets a potential buyer, while one who himself does not produce goods or services needed by the potential buyer. So, an MSME actor will help find the products needed by these potential buyers at MSMEs who are members of the CTH. Because CTH is a place for MSMEs, it will quickly find the products needed. Therefore, an MSME actor will act as a broker that brings together potential buyers who are also MSME actors who are members of CTH and outside of CTH with MSME players who will become suppliers.

Communication can occur because both are in the CTH container. After the broker brings together potential suppliers and potential buyers, the broker only monitors the communication that occurs then focuses on the communication between the supplier and the buyer. Bu Emi is a handicraft MSME practitioner in Gresik, in her business process $\mathrm{Bu}$ Emi met with prospective buyers outside $\mathrm{CTH}$, namely prospective buyers from Malaysia who needed a supply of ginger powder extract with a capacity of one ton per two months.

In short, Bu Emi contacted Pak Imam in Nganjuk who was able to meet the demand for one ton of ginger powder extract per two months. After intensive communication between Bu Emi and Pak Imam and intensive communication between Mrs. Emi and potential buyers in Malaysia, Bu Emi brought together Pak Imam with potential buyers from Malaysia. The results of the communication process required Pak Imam to send product samples for due diligence. Pak Iman also sent the requested sample. Two weeks later the prospective buyer said "OK" with the requirements that the product had to be halal certified and obtain a distribution permit. Pak Imam then again contacted Bu Emi and after saying "Ok", Bu Emi then contacted Bu Tjatur, a CTH expert staff who had experience in managing halal certification and distribution permits from BPOM.

$\mathrm{Bu}$ Emi's communication as a broker developed into dual communication, namely as a broker that brought together Pak Imam with potential buyers in Malaysia, and as a broker that brought together Pak Imam and Bu 
Tjatur. As a local entrepreneur with no export experience, Bu Tjatur then also assisted Pak Imam on export procedures and arranging distribution permits from BPOM to completion. In this process, $\mathrm{Bu}$ Emi has withdrawn somewhat from the communication process. Communication is the focus between Pak Imam and Bu Tjatur.

The communication patterns between $\mathrm{Bu}$ Emi, Pak Imam, prospective buyers, and $\mathrm{Bu}$ Tjatur are very concise, efficient, and effective because they all support each other, give each other reinforcement, empower, and benefit. This is the main benefit that has been proven by MSMEs who are members of CTH. Bu Emi stated:

"That's the fortune we are at CTH, we are not lonely, we have many friends, we have many partners, we

have a lot of business. We can sell, we can be brokers, we do business here and there ... "

The existence of $\mathrm{Bu}$ Emi as a broker between Pak Imam and potential buyers and between Pak Imam and $\mathrm{Bu}$ Tjatur is very valid. Bu Emi received a fee from Pak Imam only once, likewise, Bu Tjatur received a fee from Pak Imam once. This happened because after Pak Imam was able to independently export his products, then Pak Imam could directly contact his buyers in Malaysia. Bu Emi's existence as a broker, in practice, can "occur" several times. This is because Pak Imam has never forgotten Bu Emi or Bu Tjatur. Pak Imam stated:

"I remember $\mathrm{Bu}$ Emi and $\mathrm{Bu}$ Tjatur... I communicate sustainably to maintain and even improve business relationships... at some point in time we need, I have friends, have a consultant, have a companion... to share... as partners, of course, Bu Emi and Bu Tjatur also have to feel the consumption of our powdered ginger extract ... I am lucky and proud to join CTH ... "

Communication between suppliers and brokers and buyers also occurs among internal MSMEs members of CTH. An MSMEs owner who is in shortage of raw materials can be met by other MSMEs as a supplier with other MSMEs as brokers. This practice draws on Galbraith's applied information processing theory, which views organization $(\mathrm{CTH})$ as a complex dynamic system for ascertaining and processing information from the environment. Organizations $(\mathrm{CTH})$ need information about the availability of raw materials and markets to produce products, and organizations $(\mathrm{CTH})$ need information about how to manage raw materials. The organization $(\mathrm{CTH})$ must have this information to indicate the degree of environmental uncertainty. The uncertain environment affects how decisions are made in the organization.

For example, Pak Rudi in Lamongan is a tiger prawn and milkfish farmer, while Pak Hasan in Jombang is a catfish farmer of MSMEs. Pak Hasan has many links with MSME restaurants with either fellow or non-fellow CTH members as a regular supplier of catfish, especially with many small restaurants in Jombang, Kediri, and Mojokerto. Pak Hasan received orders for small size milkfish, namely milkfish with a length of $\pm 20 \mathrm{~cm}$ for a restaurant position. This order is not only for one restaurant, but 20 restaurants. Pak Hasan is a catfish farmer assisted by $\mathrm{CTH}$, whose products are ordered for various needs, both traditional markets and restaurant orders, as well as orders for other SMEs that produce catfish floss. When Pak Hasan received an order for milkfish $\pm 20 \mathrm{~cm}$ in length, as a member of CTH, of course, Pak Hasan found out a solution in CTH. Pak Hasan immediately contacted Pak Rudi and connected him with 20 restaurants of MSME actors.

The communication process that occurred was the same as the communication process between Pak Imam in Nganjuk and $\mathrm{Bu}$ Emi and potential buyers from Malaysia. The communication process that empowers each other, supports each other, strengthens each other, and benefits each other between suppliers, brokers, and buyers based on mutual trust. The presence of a broker is very significant in the communication process. The broker has been considered or treated as a "recommendation," as a "guarantor," and as a "custodian of the business." Of course, Pak Rudi would not just believe the information about milkfish orders if it was not Pak Hasan. Likewise, 20 restaurant MSME actors did not just believe in suppliers, if it was not Pak Hasan who delivered. Thus, Pak Hasan's position became central in communication.

Mutual trust is continuously strengthened by actions, both Bu Emi and Pak Hasan do not want to take the opportunity to become agents or resellers (users), even though the opportunity exists. Pak Hasan doesn't want to be an agent for Pak Rudi to supply milkfish to 20 MSME restaurants. This practice refers to the applied theory of the Communicative Constitution of Organizations (CCO), which states that communication is not only a peripheral epiphonema of human action but the main model for explaining social reality (Ashcraft et al., 2009). $\mathrm{CCO}$ focuses on the daily interpersonal exchange, the organization $(\mathrm{CTH})$ emerges "through the laminated tastemaking activity of members (MSMEs), endlessly renegotiated." People (MSMEs) orient themselves towards one another, leading to moments of consensus, but the consensus is constantly being renegotiated. Mutual orientation is a process that occurs constantly in interactions (Taylor \& Van Every, 2000). Communication activity is the basis, which defines the "stuff" in organizational life (CTH). Without communication, the organization (CTH) no longer exists as a meaningful human collective (MSME). Organization (CTH) is not just a physical place where people (MSMEs) communicate. In contrast, organization (CTH) exists because people (MSMEs) communicate, creating a complex system of meaning called "organization (CTH)" (Mumby, 2013). This analysis is reinforced by Pak Hasan's interview sample which states:

"Based on experience, in CTH everything is possible ... easy ... each of us can meet each other. I don't want to be an agent, just become a broker, and that's enough only once after that I let the restaurant owner immediately communicate and negotiate with Pak Rudi himself.... In CTH, we establish a living 
communication that brings each other to life.... Let's be honest, I have been raising catfish for decades... I won't even focus on catfish if I'm adventurous to be a milkfish agent... "

The same thing was said by Bu Emi:

"Honestly, I can be a user who resells ginger extract products to my buyers in Malaysia ... I bought from Pak Imam and I resold to my buyer in Malaysia ... if I did that at that time, surely Pak Imam would not know ... but no ... if I became an agent ... in the end, Imam would know ... because in CTH there was communication between fellow members is very open... if I become an agent and then $\mathrm{Mr}$. Imam knows...

CTH : Communication of Organic Adhocracy Empowerment of MSMEs Large Family in the future we will not have any partners in $\mathrm{CTH}$, my reputation as an individual and as an entrepreneur and also as a member of CTH could be damaged...."

The dominant lateral communication in CTH refers to the application of McGregor's theory of Y. CTH management views that MSMEs actors have the capacity and motivation, and have the potential to take responsibility. This is marked by decentralized decision making and more delegation of responsibility to MSMEs. Enrichment of jobs at the organizational level at the bottom will help MSMEs accept responsibility. Inviting MSME actors to participate in decision making, because with participation, MSMEs may show commitment to the goals of CTH, and at the same time the needs of MSME actors or owners will be fulfilled (Berry, 1998).

\section{Grounded Theory}

Non-profit organizations such as CTH can survive, function, and take a strategic role as the head of a large family in a sustainable manner by merging into the members' MSME business; involve expert staff, consultants, entrepreneurs, trainers, mentors, and other professionals in the project team; implement empowerment business communication patterns with a spirit of brotherhood, friendship, cooperation to live and nurture and strengthen each other for the sake of mutual progress; and develop ethics of honesty, mutual trust, mutual interest, and fairness in profit sharing.

\section{Implications, Limitations, and Areas of Advanced Research}

The theory of adhocracy and the configuration of organic organizations have relevance to the organization of CTH. On the other hand, CTH also shows the configuration of power or control structures in the hands of the director and expert staff. Configuration of professional and divisional structures on empowerment projects at $\mathrm{CTH}$ is in the hands of professional operators, namely expert staff, consultants, entrepreneurs, trainers, assistants, and empowerment of MSMEs. CTH has implications for theoretical development in organizational theory because it has a complex configuration and influences administrative management practices and organizational behavior with high volume loads. This will have implications for the need for managerial innovation, organizational learning, and proactive information technology which will help reduce the operational burden of management.

The communication theories used in this study have relevance to the practice of CTH communication. On the other hand, $\mathrm{CTH}$ also shows a social and ethical configuration in communication. The social configuration appears in a small body of a very simple organizational structure but looks very large because it contains members of nearly 7 million MSMEs. CTH has implications for theoretical development in organizational communication theory because it bears the burden of communication traffic of 7 million members which is very crammed and if it is not resolved, it will likely cause congestion and even reverse flow in the form of decreased communication. This will have implications for the need for a web template that sorts communication traffic by sectoral lines which will help reduce the operational burden of communication between the management and the MSME members of CTH.

This study was unable to reach a richer range of themes from more key informants from various business sectors. This study recommends future research to involve research teams in a more specific area with an analysis per business sector so that sources of bias can be eliminated.

\section{References}

Ashcraft, K. L., Kuhn, T., \& Cooren, F. (2009). Constitutional amendments: "Materializing" organizational communication. Academy of Management Annals, 3, 1-64. doi: 10.1080/19416520903047186

Atwood, C. G. (2009). Knowledge management basics: A complete how-to guide. Alexandria, VA: ASTD Press.

Berry, L. M. (1998). Psychology at Work: An Introduction to Industrial and Organizational Psychology. International Edition. Psychology Series. New York: McGraw-Hill. 2nd Ed.

Broome, B. J. (2009). Dialogue theories. In S. W. Littlejohn \& K. A. Foss (Eds.), Encyclopedia of communication theory (pp. 301-305). Los Angeles, CA: Sage.

Conduit, J., \& Mavondo, F. T. (2001). How critical is internal customer orientation to market orientation? Journal of Business Research, 51, 1, 11-24. doi:10.1016/S0148-2963(99)00044-2 
Covin, J. G., Slevin, D. P., and Schultz, R. L. (1994). Implementing Strategic Missions: Effective Strategic, Structural, and Tactical Choices. Journal of Management Studies, 31, 481-505. doi.org/10.1111/j.14676486.1994.tb00627.x

Dance, F. E. X. (1967). Human communication theory. New York, NY: Harper, Row Publishers.

CTH : Communication of Organic Adhocracy Empowerment of MSMEs Large Family

deLeon, L. (1993). As Plain and 1, 2, $3 \ldots$ and 4 Ethics and Organization Structure. Administration \& Society, 25, 3, 293-316. doi:10.1177/009539979302500302

Gibson, J. L., Ivancevich, J. M., \& Donnelly Jr, J. H. (1994). Organization Behavior, Structure, Process. Illionis: Irwin.

Grunig, L. A., Grunig, J. E., \& Dozier, D. M. (2002). Excellent public relations and effective organizations: A study of communication management in three countries. Mahwah, NJ: Erlbaum.

Jablin, F. M., \& Putnam, L. L. (2001). New handbook of organizational communication. London: Sage.

Minner, J. B. (1998). Organizational Behavior, Performance and Productivity. USA: Random House Inc.

Monge, P. R., \& Contractor, N. S. (2003). Theories of communication networks. NY: Oxford University Press.

Mumby, D. K. (2013). Organizational Communication, A Critical Approach. USA: Sage Publications, Inc.

Neumann, W. R. (2008). Interaction. In W. Donsbach (Ed.), The international encyclopedia of communication (Vol. V, pp. 2305-2309). Malden, MA: Blackwell.

Nonaka, I., \& Takeuchi, H. (1995). The knowledge-creating company: How Japanese companies create the dynamics of innovation. NY: Oxford University Press.

Quirke, B. (2000). Making the connections; Using internal communication to turn strategy into action, Gower: Aldershot.

Ritzer, G. (2000). Classical sociological theory. Boston,MA: McGraw-Hill.

Schoeneborn, D., \& Blaschke, S. (2014). The three schools of CCO thinking: Interactive dialogue and systematic comparison. Management Communication Quarterly, 28, 285-316. doi.org/10.1177/0893318914527000

Taylor, J. R., \& van Every, E. J. (2000). The emergent organization: Communication as its site and surface. Mahwah, NJ: Erlbaum.

van Ruler, B. (2018). Communication Theory: An Underrated Pillar on Which Strategic Communication Rests. International Journal of Strategic Communication, 12, 4, 367-381. doi.org/10.1080/1553118X.2018.1452240

Welch, M., \& Jackson, P. R. (2007). Rethinking internal communication: A stakeholder approach. Corporate Communications: An International Journal, 12, 2, 177-198. doi.org/10.1108/13563280710744847

Wrench, J. S. (2012). Communicating within the modern workplace: Challenges and prospects. In J. S. Wrench (Ed.), Workplace communication for the 21 st century: Tools and strategies that impact the bottom line: Vol. 1. Internal workplace communication. Santa Barbara, CA: Praeger.

Wrench, J. S., McCroskey, J. C., \& Richmond, V. P. (2008). Human communication in everyday life: Explanations and applications. Boston, MA: Allyn \& Bacon. 